\title{
A Study of Babies' Scenes in the Ancient Egyptian Private Tombs
}

\author{
Mona Ezz \\ Faculty of Tourism and Hotels - Mansoura University
}

\begin{abstract}
Tombs scenes reflected how the ancient Egyptians be concerned with their babies. According to the instruction of any; the baby should be suckled for about three years to strengthen his immunity; this was to reduce the chances of the mother to be pregnant. Babies were to grow up with their mothers who superbly concerned with them during this period. ${ }^{1}$ From the tombs' scenes; it is obvious how the ancient Egyptians cared about their babies on the contrary to the babies of the foreign women. Moreover, such scenes reflected the different positions in which the babies appear, and the difference between the babies of the common people, high class, and the babies of the foreigners and the slaves. Furthermore, these scenes also depict the scenes of deities while nursing the kings.
\end{abstract}

Keywords: Babies, private tombs, Ancient Egypt.

\section{Introduction}

The ancient Egyptians used many terms to refer to the child like inpw, sif, sri, Xrd, ms, aDd, nfr, idw, kti, Hwn, nxn wdH , x, TAi, idw, idiit, mnH. However, it seems that $\mathrm{x}$, wdH, and TAi were specifically referring to the newborn babies. $^{2}$

The ancient Egyptians used to hire wet nurses, especially, the royal families and the elites as they considered this is more prestigious. In other cases, wet nurses were hired when the mother had been died or suffered from the shortage in her milk. Nurses came to live with the baby in his home. The baby parents were to pay for them. During this time, nurses were obliged to do not suckle any other baby, to do not be pregnant, and to do not has any sexual relations. ${ }^{3}$ The parents make a contract with the nurse; determine the period of nursing their baby, the fixed salary, and all the demanded conditions. ${ }^{4}$ In some cases, the nurse stays with the child until growing up, hence, the nurse will perform the teacher's duties. ${ }^{5}$ Babies appeared in different scenes accompanying their mothers and their wet nurses in different positions and places, like the following scenes;

\section{Scenes showing servants and peasants suckling their babies}

- The scene which appeared at the tomb of Ny ankh Khnum and Khnum Hotep from the $6^{\text {th }}$ dynasty at Saqqara shows a female servant while baking bread. She is depicted wearing a short kilt, while the upper part of her body is naked. She looks exhausted owing to the oven's heat, and so she is protecting her face by her right hand. In her left hand, she holds a stick to poke the fire. She places her baby over her right raised knee. The baby is at his mother's left breast, and catches her nipple with his right hand to squeeze her milk into his mouth. Therefore, the mother couldn't embrace her baby like the usual attitude, as she is involved in her hard labor (fig. 1). ${ }^{6}$

- The scene which appeared at the tomb of Menna (TT 69) from the $18^{\text {th }}$ dynasty at Sheikh Abd El-Qurna. It depicts one of the female peasants seated under a tree, and collecting figs, while nursing her baby. She wraps the baby around her body by a wide shawl. Only his head and legs are unwrapped. The baby is grasping his mother's hair by his hands in a great emotional scene. This reflected the close relation between the baby and his mother (fig. 2). ${ }^{7}$

- Scene at the tomb of Baket III of $12^{\text {th }}$ dynasty at Beni Hassan shows a tax collector punishing a woman who is represented embracing her baby between her arms (fig. 3). ${ }^{8}$

\section{Scenes showing babies while suckling from their mothers on a ship}

- The scene which appeared at the tomb of Ptah Hotep from the $5^{\text {th }}$ dynasty at Saqqara, it depicts a woman while breastfeeding her baby on the cabin of cargo ship. She is wearing a dress with two hanging straps attached to the shoulders to facilitate suckling her baby. She is carrying her baby on her left arm; and grasps her left breast by her right hand (fig. 4). ${ }^{9}$

- The scene which appeared at the tomb of Kagemni from the $6^{\text {th }}$ dynasty at Saqqara, it depicts a woman seated on the board of a ship while breastfeeding her baby. She is wearing a long dress with two hanging straps to enable her to breastfeed her baby. She carries the baby on her two legs; supporting his head on her right arm, while she holds her right breast with her left hand, so enables her baby to squeeze milk from her right breast (fig.5). ${ }^{10}$

- The third scene appeared at the tomb ${ }^{\circ}$ TT 143 from the $18^{\text {th }}$ dynasty at Dra Abu El-Naga. It depicts an Egyptian woman while squatting at a ship's deck and nursing her baby. Probably, she is the wife of an Egyptian representative who traveled in commercial expedition to bring several productions from Punt. The woman wears a strapless dress and breastfeeding her baby from her right breast. She is pressing over her nipple with her left hand's thumb, and the rest of the fingers are under the nipple so the milk will smoothly flow to her baby's mouth. This scene is a part of the return voyage from punt (fig. 6). ${ }^{11}$ 


\section{Scenes showing babies suckle from wet nurses}

- The scene which appeared at tomb of Khety of the $11^{\text {th }}$ dynasty at Beni Hassan, it depicts a wet nurse squatting on the ground. She is wearing a long dress with two shoulders' straps. She holds the baby on her right raised knee to be close to her right breast. She supports him by her right arm, and pushing her breast's nipple on her baby's mouth by the other hand. Opposite to the nurse; one of the musicians and a singer are seated and trying to pacify the young baby with their music (fig.7). ${ }^{12}$

In this scene, there are apparent differences between the common mothers and wet nurses who were hired to nurse babies of the elite people. Common mothers were represented suckling their babies while practicing their usual works, like the previous scenes showing mothers baking bread, or gathering figs while suckling their babies. However, in the case, wet nurses were prevented to act any activity except nursing the baby, and the parents supply her with all suitable surroundings to suckle their babies.

\section{Scenes showing babies of the foreigners}

- The scene which appeared at the tomb of Khonum Hotep of the $12^{\text {th }}$ dynasty at Beni Hassan shows a group of Libyan women wearing long skirts and carry their babies in baskets, which in turn placed at their backs. In this position, both emotion and passion are missing (fig. 8). ${ }^{13}$

- The scene which appeared at the tomb of Maii of the $18^{\text {th }}$ dynasty at Saqqara shows one of the Syrian slaves while carrying her baby on her left arm. She holds him in a sling wrapped around her shoulder (fig. 9). ${ }^{14}$

- The scene which appeared at the tomb of Mery Re ii of the $18^{\text {th }}$ dynasty at El Amarna shows a group of Nubian women carrying their babies within baskets on their backs (fig. 10). ${ }^{15}$

- The scene which appeared at the tomb of Amonuser (TT 131) of the18 ${ }^{\text {th }}$ dynasty at Sheikh Abd El-Qurna shows an Asiatic woman carrying her baby on a basket on her left shoulder. The baby's head emerges from the basket's top (fig. $11)^{16}$

- The scene which appeared at the tomb of Amenmose (TT 89) of the18 ${ }^{\text {th }}$ dynasty at Sheikh Abd El-Qurna shows a couple of Nubian women carrying their babies within panniers on their backs (fig. 12). ${ }^{17}$

- The scene which appeared at the tomb of Rekhmire (TT 100) of the $18^{\text {th }}$ dynasty at Sheikh Abd El-Qurna shows different scenes of the foreign babies, identical to one of the scenes showing the Nubian women with naked breasts, and carry their babies within baskets on their backs (fig. 13). ${ }^{18}$ However, another scene depicts Asiatic women carrying their babies in different ways; one of them carries her baby on a sling wrapped around her shoulder, another one carries her baby on her shoulders and the baby placed his hands on her forehead, and the third one carries her baby within a basket laid on her back (fig. 14). ${ }^{19}$ The third scene showed Syrian slaves; and among is a woman carrying her baby on her shoulder, who grasps his mother's hair by both hands (fig. 15). ${ }^{20}$

\section{Scenes showing babies in funerals}

- The scene which appeared at the tomb of Nefer Hotep (TT 49) of the $18^{\text {th }}$ dynasty at Khokha shows a group of babies in a funeral in the companion of their mothers. Accompanying babies in funerals refers that those mothers were attributed to the lower social class, because if they had wet nurses; they were able to leave babies with them. Those mothers carried their babies on shawls wrapped around their chests, and put them closely to their hearts, except for one mother holds her baby on her back. This was a young girl who had insufficient experience about how to carry a baby; besides, she appeared as if she is carrying a heavy burden on her back (fig. 16). ${ }^{21}$

\section{Scenes showing the king in the form of a baby}

Kings were likewise represented in the form of babies, but were represented while suckling from deities, like the following scenes;

- The scene which appeared at the tomb of Amenhotep (TT 48) of the $18^{\text {th }}$ dynasty at Khokha. It depicts Renenutet the goddess of harvest in the human body and the head of a serpent, and surmounted by the solar disc flanked by two horns and feathers. She nurses King Amenhotep III, who is represented as a baby seated on her lap, and wearing the royal hair wig. She rests him on her right arm and breastfeeding him from her right breast. She gets her breast out by her left hand. At this time, the king played the role of her son "god Nepry"(fig. 17). ${ }^{22}$

- The scene which appeared at the tomb of Khamhat (TT 57) of the $18^{\text {th }}$ dynasty at Sheikh Abd El-Qurna shows goddess Renenutet in a human body and the head of a serpent, and surmounted by two long feathers. On her lap; the goddess is carrying the infant king, who is shown while suckling milk from her left breast (fig. 18). ${ }^{23}$

- The scene which appeared at the tomb of nfr rnpt (TT 336) of the 19th dynasty at Deir el Madina shows the goddess Mrt Seger in a whole human body while breastfeeding a naked infant king. The goddess rests the baby's nape by her left hand, holds her left breast by the other hand, and lifts her right foot up to draw the child near to her breast (fig. 19). ${ }^{24}$

\section{It is noticed from the studied scenes that;}

- Only female peasants and the slaves (the commoner) were depicted in the tombs' scenes while breastfeeding their own babies. 
- Babies of the peasants and the slaves were depicted in the companion of their own mothers; who were participating in their principal work. Of these, the scene of a servant breastfeeding her baby while baking bread, and the peasant who was involved in gathering figs while breastfeeding her baby. In the contrary, mothers of the high social elite who appeared only in some ostraca while breastfeeding their babies, and was surrounded with servants taking care of her. Of these, a servant is massaging her feet, another one holding a mirror for her, and behind is a small monkey. All these aspects reflected the great care specified to the elite mothers (fig. 20). ${ }^{25}$

- Wet nurses who appeared breastfeeding the babies weren't charged with any mission or activity except for the purpose they were hired for. According to a legal agreement between the parents and those nurses; this prevent nurses from nursing another baby through this agreement.

- When a wet nurse or a mother suckles a baby; she appeared kneeling or squatting on the ground, and supporting the baby on her knee or thigh. While, when appeared seated; she positioned the baby on her thigh, and bending down to the baby's level on her legs. However; in all cases, she carried the baby on one arm, and held out her breast by the other.

- In the selected scenes; women were represented nursing babies in any situation; while listening to music, being beaten for not paying taxes, sailing on boats, baking bread, or while gathering figs. These scenes assure that babies in the first three years are in bad need of the care of their mothers or their wet nurse either, who in turn accompany them everywhere.

- Babies were carried enfolded or placed within shawls around their mothers' waist to enable them practicing their labors and activities; such as gathering figs through funeral processions.

- Unlike Egyptian women; foreign mothers took care of their babies in a different way. They placed their babies within baskets, such as the Libyan slaves in the tomb of Khnum Hotep, and the Nubians in the tombs of (Mery Re ii, Imnmose, Rekhmire). While the Syrians used to carry their babies in slings wrapped around their waist, such as in the tomb of Maii. Another scene at the tomb of Rekhmire, shows them carrying babies over their shoulders. While the Asiatic ones carried their babies in different positions; sometimes over their shoulders, in a sling wrapped around their waists, and within baskets similar to the Nubian way.

- The scenes depicted Egyptian women taking care of their babies more than the foreigners did. Egyptian women used to hang their babies on a sling attached to their breasts, and rarely hold them on their backs like the Nubians. Such way seems as a neglecting way. However, the Egyptians way of carrying their babies on their arms appear as embracing their babies.

- Kings were depicted in the form of babies while suckling from the goddesses, and so gains protection and assure the shifting from the humanity to the divinity.

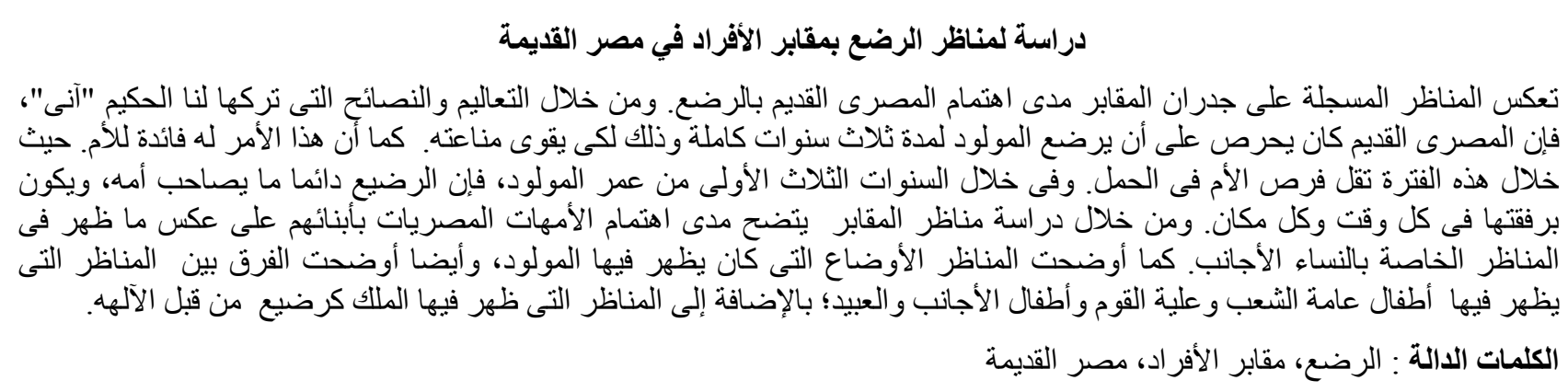




\section{Figures}

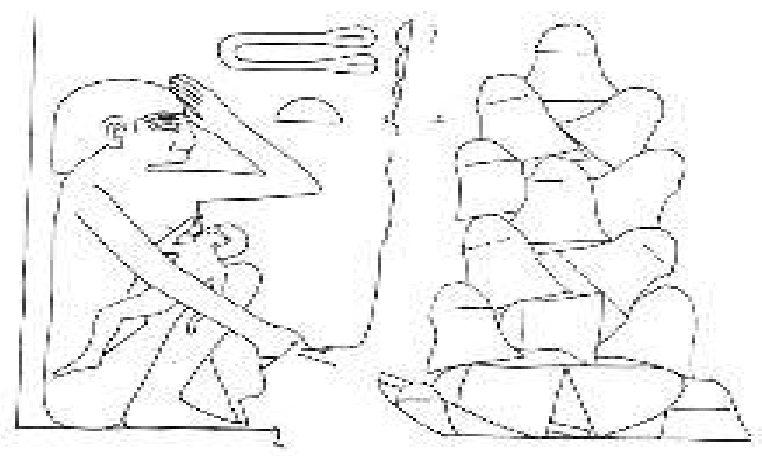

Fig. (1) A scene representing woman breastfeeding her baby while making the bread, tomb of Ny ankh Khnum and Khnum Hotep, Saqqara, $5^{\text {th }}$ dynasty.

After H.G. Fischer (2000), Egyptian Women of the Old Kingdom. New York, fig. 7

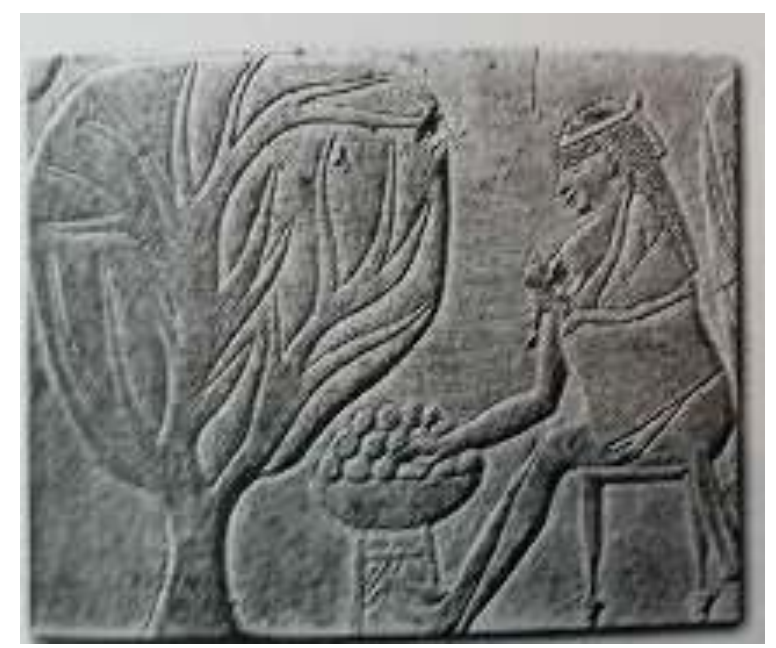

Fig. (2) A scene representing a woman nursing her baby while gathering figs, tomb of Menna, Sheikh Abd El -Qurna, $18^{\text {th }}$ dynasty.

After S.E. Hodel Hoenes (2000), life and death in ancient Egypt. Scenes from private tombs in new kingdom Thebes, translated from the German by D. Warburton. London, fig. 58

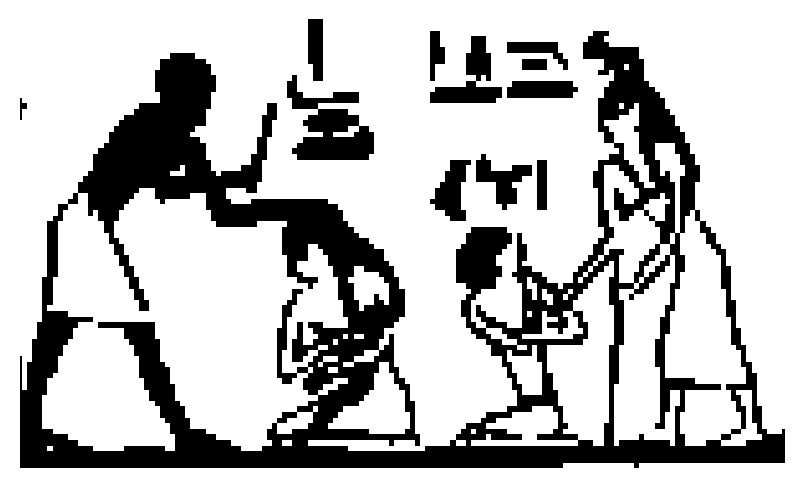

Fig. (3) A scene representing a baby in the bosom of his mother who is punished by the tax collector, tomb of Baqet iii, Beni Hassan, $11^{\text {th }}$ dynasty.

After P.E. Newberry (1893), Beni Hassan II, Archaeological Survey of Egypt Memoir II.London, pl. vii 


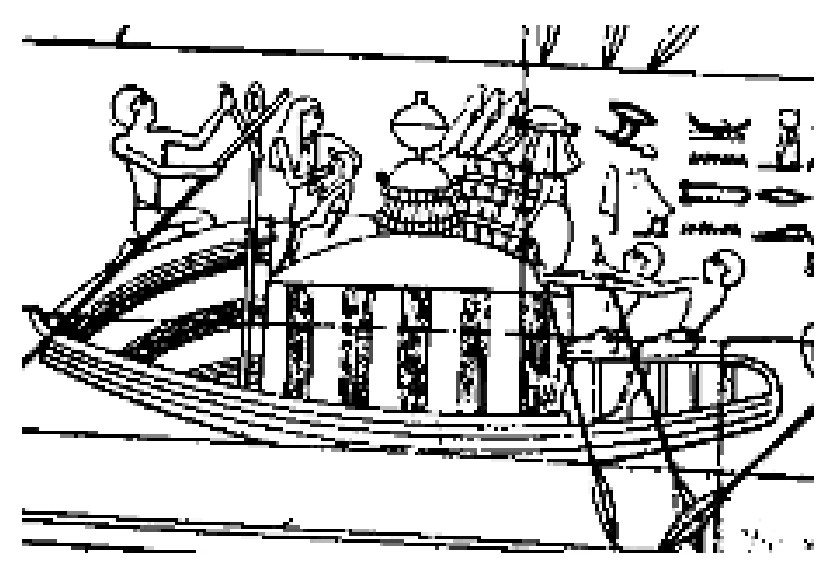

Fig. (4) A scene representing a woman nursing her baby on the cabin of cargo ship, a tomb of Ptah Hotep, Saqqara, $5^{\text {th }}$ dynasty.

After J. Vandier (1969), Manuel d' archéologie Ëgyptienne V. Bas reliefs et peintures. Scenes de la vie quotidienne.

Paris,fig. 296, 4

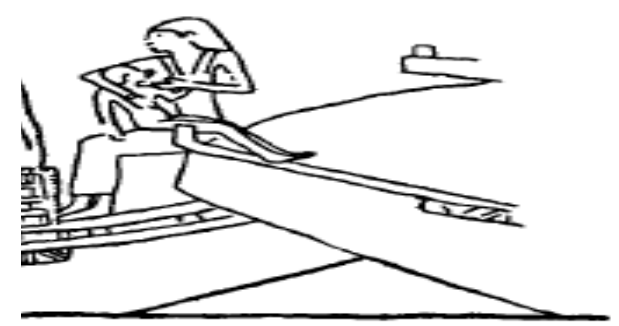

Fig. (5) A scene representing a woman nursing her baby on the board of a ship, tomb of kagemni, Saqqara, $6^{\text {th }}$ dynasty After W. St. Smith (1949), A History of Egyptian Sculpture and Painting in the Old Kingdom. London, fig. 155

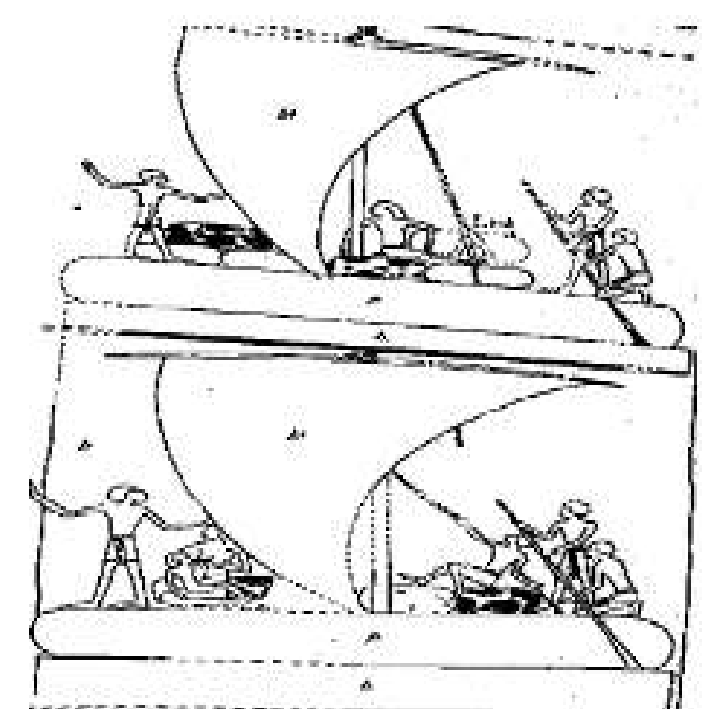

Fig. (6) A scene representing a woman breastfeeding her baby on the deck of the ship,a tomb without name, dra abu el naga, $18^{\text {th }}$ dynasty

After N. De G. Davies (1935), " the work of the graphic Branch of the expedition", BMMA xxx, $\mathrm{n}^{\circ}$ 9, fig. 2 


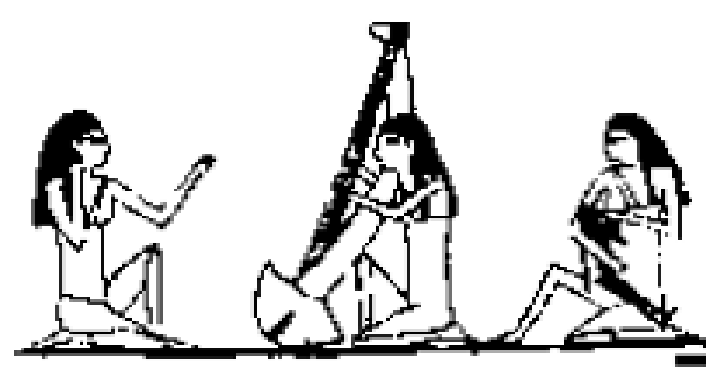

Fig. (7) A scene representing a baby suckling from a wet nurse sitting beside a female singer and a musician, tomb of khety, Beni Hassan, $11^{\text {th }}$ dynasty

After P.E Newberry, op. cit., pl. xvi

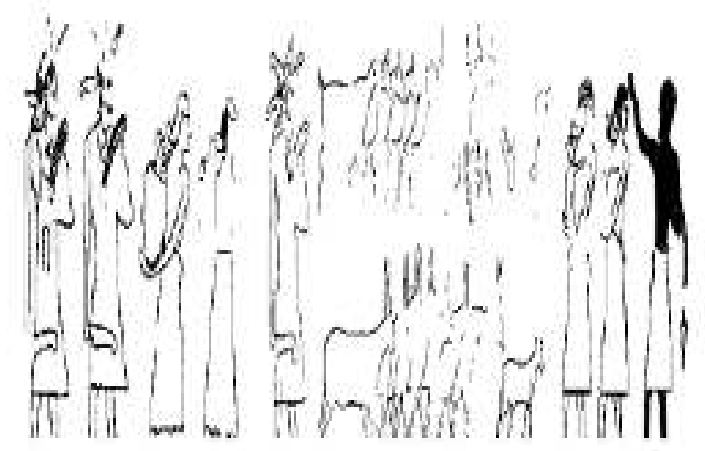

Fig. (8) A scene representing Libyan women while carrying their babies in baskets, Tomb of khnmw Hotep, Beni Hassan, $12^{\text {th }}$ dynasty

After P.E Newberry, op. cit., pl. xlvii

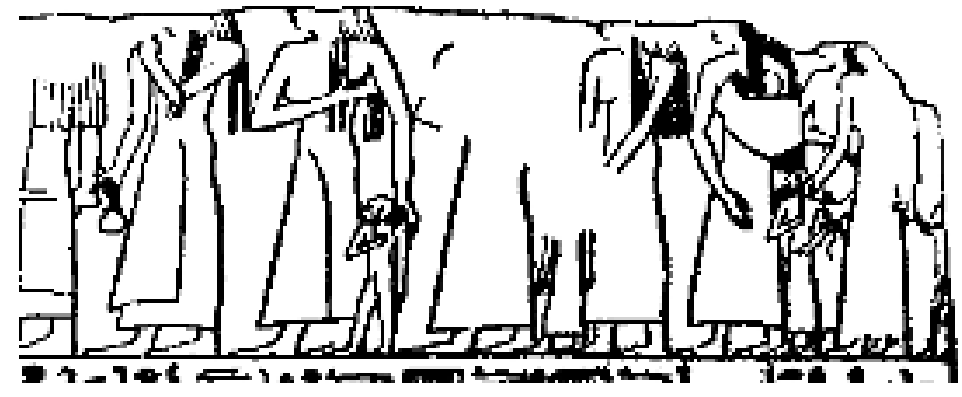

Fig. (9) A scene representing a syrian woman carrying her baby on a sling wrapped around her shoulder, Tomb of maii, saqqara, $18^{\text {th }}$ dynasty

After J. Vandier, Manuel d' archéologie Ëgyptienne, fig. 126, 3

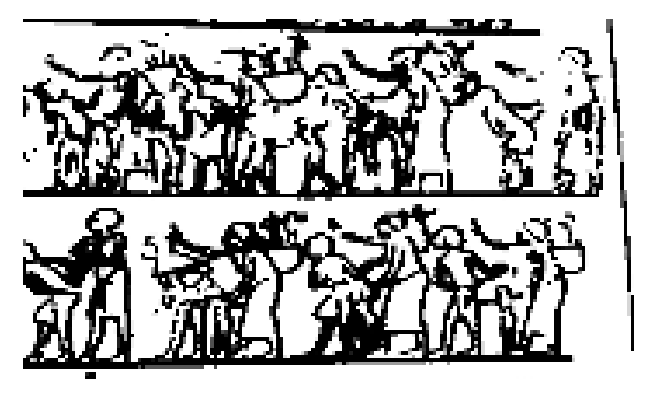

Fig. (10) A scene representing Nubian women carrying their babies on baskets at their back, Tomb of Mery Re II, el amarna, $18^{\text {th }}$ dynasty

After J. Vandier, op. cit., pl. xvii 


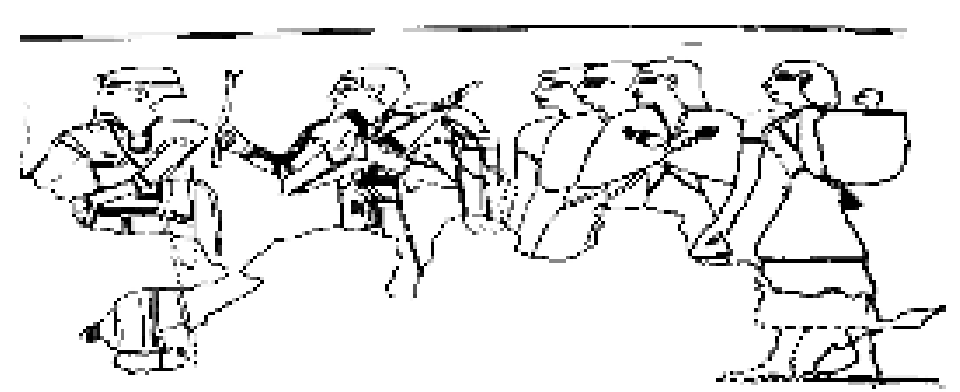

Fig. (11) A scene represents an Asiatic woman carrying her baby on a basket at her shoulder, Tomb of Amonuser, $18^{\text {th }}$ dynasty, Sheikh Abd El-Qurna.

After J. Vandier, op. cit., fig. 317b

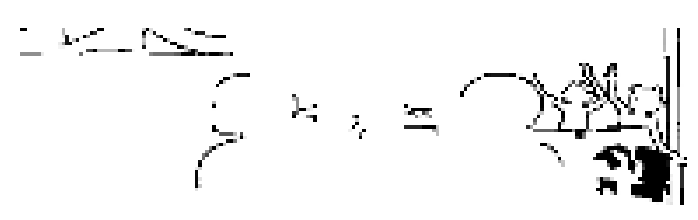

Fig. (12) A scene represents Nubian women carrying their babies on baskets at their back, Tomb of Amenmose, Sheikh abd el qurna, $18^{\text {th }}$ dynasty.

After N.M. and N. De G. Davies (1950), " the tomb of Amenmosě (No 89)", JEA xxxvi, pl. xxiv

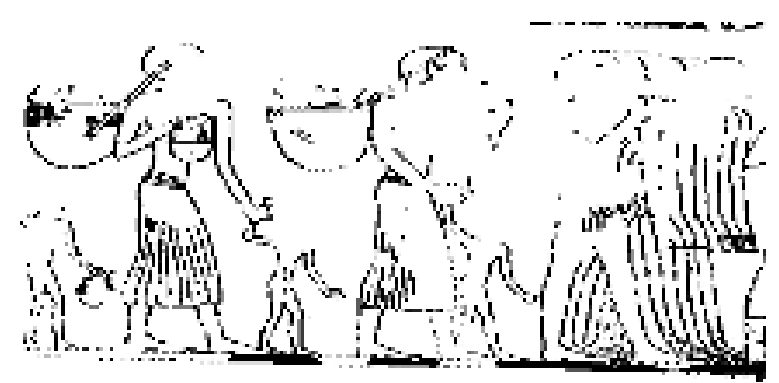

Fig. (13) A scene represents Nubian women carrying their babies on baskets at their back, Tomb of Rekhmire, Sheikh abd el qurna, $18^{\text {th }}$ dynasty.

After N. De G. Davies (1973), the tomb of Rekh mi RÉ at Thebes. New York, pl. xxi

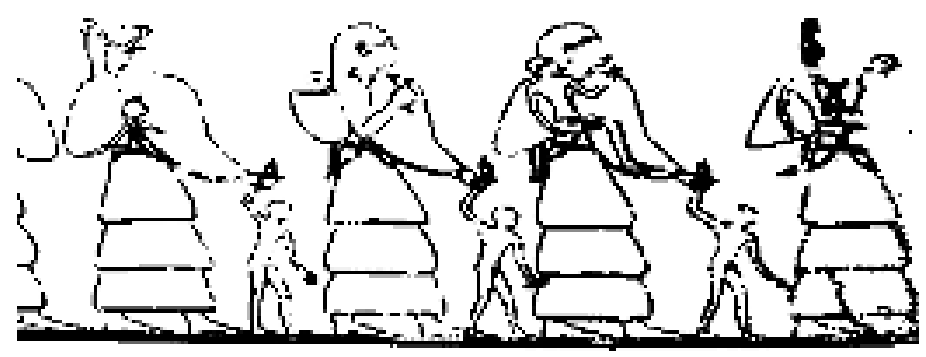

Fig. (14) A scene represents Asiatic women carrying their babies in several positions, Tomb of Rekhmire, Sheikh Abd El-Qurna, $18^{\text {th }}$ dynasty.

After N. De G. Davies, op. cit., pl. xxiii 


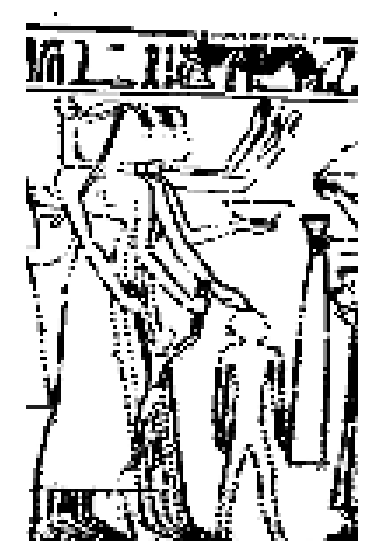

Fig. (15) Ascene represents a Syrian slave carrying her baby on her shoulders, Tomb of Rekhmire, Sheikh Abd ElQurna, $18^{\text {th }}$ dynasty.

After N. De G. Davies, op. cit., pl. lvii

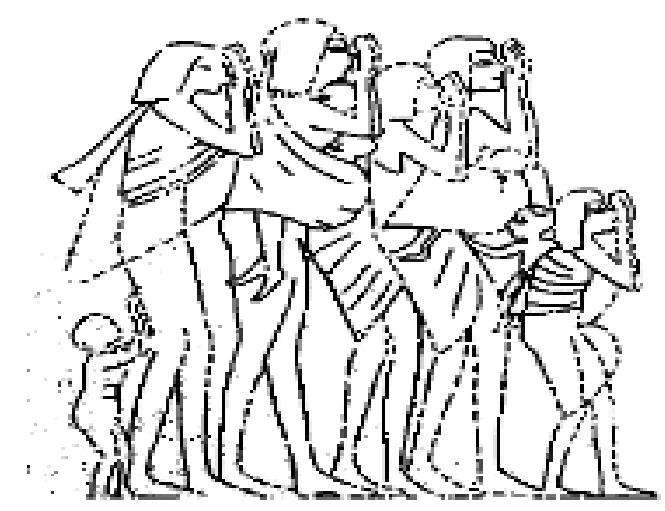

Fig. (16) Ascene represents babies carried on shawls tied around the shoulders of female mourners in a funeral procession, Tomb of Nefer hotep, Khokha, $18^{\text {th }}$ dynasty.

After N. De G. Davies (1933), The tomb of Nefer Hotep at Thebes, MMAEE IX. New York,, pl. xxiv.

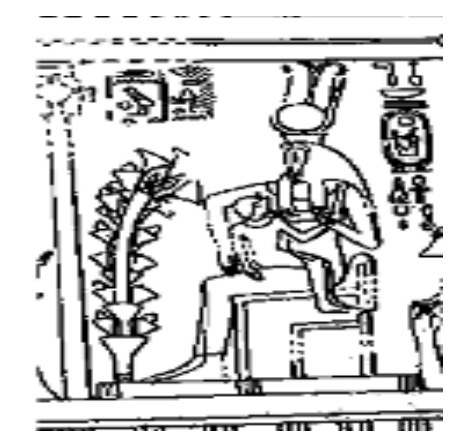

Fig. (17) A scene represents goddess Renenutet nursing king Amenhotep III, Tomb of Amenemhat, Khokha, $18^{\text {th }}$ dynasty

After T. Säve söderberge (1957), private Tombs at Thebes. Four eighteenth dynasty tombs, PTT I. Oxford, pl. xlvii 


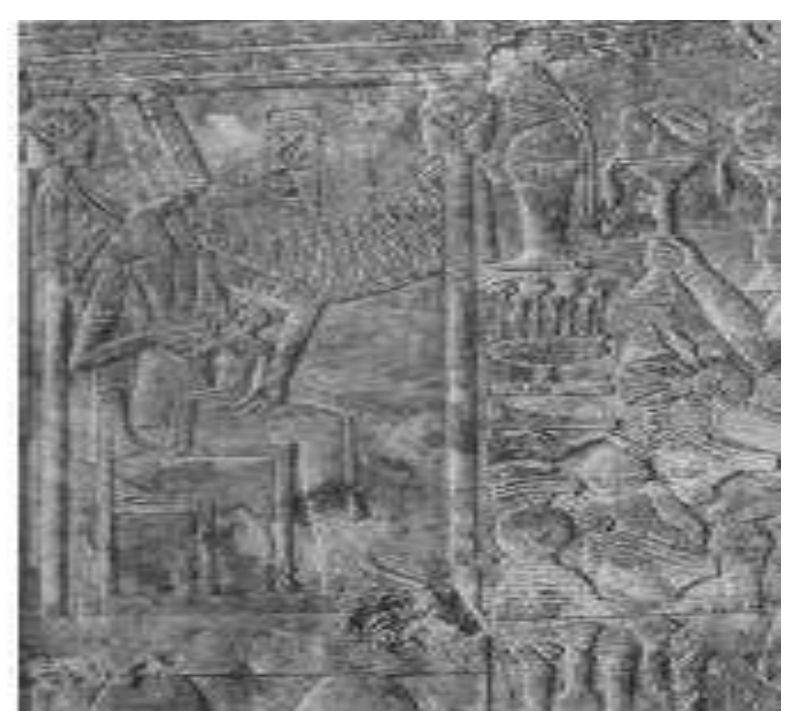

Fig. (18) A scene representing goddess Renenutet nursing an infant king, Tomb of Khatemhat, Sheikh abd el qurna, $18^{\text {th }}$ dynasty

After L. Pinch- Brock (2001), "the tomb of Khaemhat", in K. Weeks (ed.), treasures of the Valley of the Kings. Cairo, fig. 371

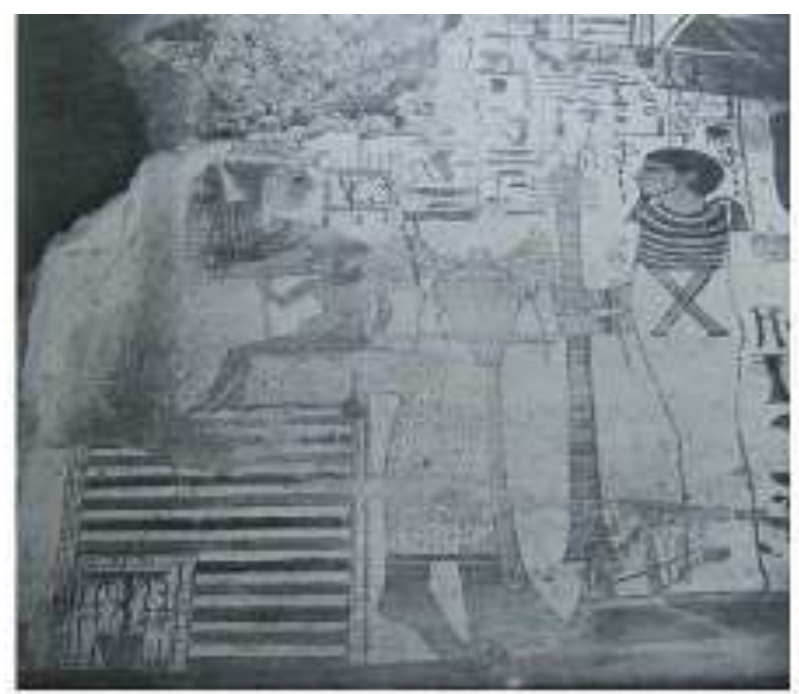

Fig. (19) A scene representing an infant king suckled by goddess Meret Seger, Tomb of Nefer renpet, Deir El Madina, $19^{\text {th }}$ dynasty

After B.Bruyére (1926), Rapport sur les fouilles de Deir El Médineh (1924-1925), FIFAO III. Le Caire, fig. 57

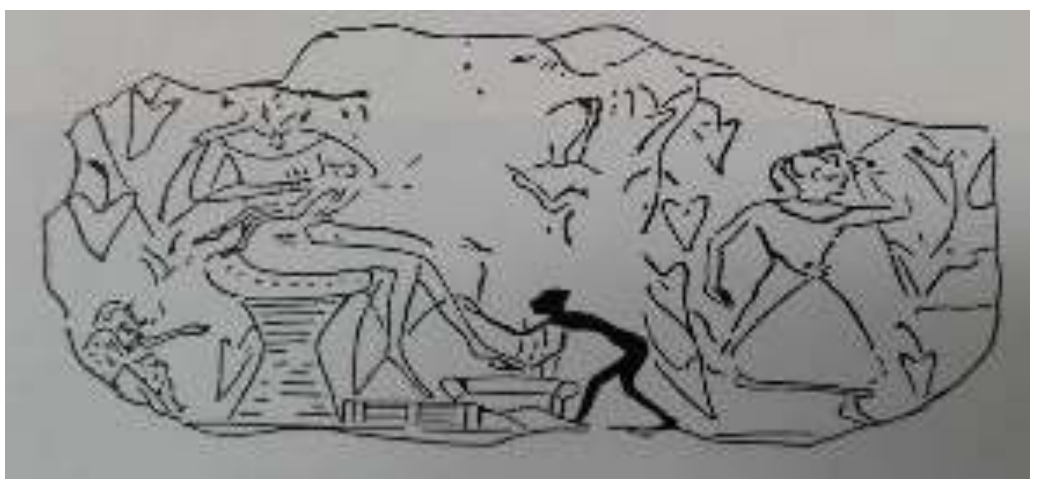

Fig. (20) A scene on an ostracon showing one of the elites while nursing her baby After A.R. Schulman (1985), “A birth Scene (?) From Memphis”, JARCE XXII, fig.3 


\section{Endnotes}

${ }^{1}$ Hawass, Z. (1995), Silent Images. Women in Pharaonic Egypt. Cairo, p. 85

${ }^{2}$ Feucht, E. (1995), Das kind im Alten Ägypten. Die Stellung des Kindes in Familie und Gesellschaft nach altägyptischen Texten und Darstellungen. Frankfurt, p.503- 549.

${ }^{3}$ Graves - Brown, C. (2010), Dancing for Hathor. Women in Ancient Egypt. London, p. 83

4 Tyldesley, J.A. (1994), Daughters of Isis. Women of Ancient Egypt. London, p. 78.

5 FEUCHT, E. (2001), " childhood," in Donald B. Redford, ed., The Oxford Encyclopedia of Ancient Egypt I.Oxford, p. 262.

${ }^{6}$ Fischer, H.G. (2000), Egyptian Women of the Old Kingdom. New York, p. 9,fig. 7

${ }^{7}$ Hodel- Hoenes, S.E. (2000), life and death in ancient Egypt. Scenes from private tombs in new kingdom thebes, translated from the German by D. Warburton. London, p. 89, fig. 58

${ }^{8}$ Newberry, P.E. (1893), Beni Hassan II, Archaeological Survey of Egypt Memoir II. London, pl. vii

${ }^{9}$ Vandier, J. (1969), Manuel d' archéologie Egyptienne V. Bas reliefs et peintures. Scenes de la vie quotidienne. Paris, fig. 296, 4; Fischer, H.G. ,op. cit., p. 38,fig. 28

${ }^{10}$ Smith, W. St. (1949), A History of Egyptian Sculpture and Painting in the Old Kingdom. London, p.301, fig. 155

${ }_{11}^{11}$ Davies, N.De G. (1935), " the work of the graphic Branch of the expedition", BMMA xxx, ${ }^{\circ} 9$, p. $48-9$, fig. 2

${ }^{12}$ Newberry, P.E, op. cit., p. 60, pl. xvi; FeUCHT, E. (1980), " kind," in W. Helck and E. Otto, ed., LÄ III. Wiesbaden, p. 425 .

${ }^{13}$ Newberry, P.E , op. cit.,p. 85, pl. xlvii

${ }^{14}$ Vandier, J. op. cit., fig. 126, 3

${ }^{15}$ Ibid., 963-4, pl. xvii

${ }^{16}$ Ibid.,586, fig. $317 \mathrm{~b}$

${ }^{17}$ Davies, N.M. and N. De G. ( 1950), " the tomb of Amenmosě (No 89)", JEA xxxvi , pl. xxiv

${ }^{18}$ Davies, N. De G. (1973), the tomb of Rekh mi RÉ at Thebes. New York, p. 29, pl. xxi

${ }^{19}$ Ibid., p.30, pl. xxiii

${ }^{20}$ Ibid.,p.47, pl. lvii

${ }^{21}$ Davies, N. De G. (1933), the tomb of Nefer Hotep at Thebes, MMAEE IX. New York, p.40, pl. xxiv.

${ }_{22}$ Säve söderberge, T. (1957), private Tombs at Thebes. four eighteenth dynasty tombs, PTT I, .Oxford, p.42, pl. xlvii

${ }^{23}$ Pinch- Brock, L. (2001), "the tomb of Khaemhat", in K. Weeks (ed.), treasures of the Valley of the Kings. Cairo, p.370, fig. 371

${ }^{24}$ Bruyére, B. (1926), Rapport sur les fouilles de Deir El Médineh (1924-1925), FIFAO III. Le Caire, p. 86-7, fig. 57

${ }^{25}$ Schulman, A.R. (1985), "A birth Scene (?) from Memphis", JARCE xx , p. 99-100, fig.3 